\title{
Dyskurs akademicki jako praktyka społeczna. Zwrot dyskursywny i Społeczne Badania Szkolnictwa Wyższego
}

\section{KEYWORDS}

discourse analysis, Higher Education Studies, poststructuralism, Social Studies of Higher Education, pragmatics, methodology

\begin{abstract}
Wróblewska Marta Natalia, Angermuller Johannes, Dyskurs akademicki jako praktyka społeczna. Zwrot dyskursywny i Społeczne Badania Szkolnictwa Wyższego [Academic discourse as a social practice. For a discursive turn and Social Studies of Higher Education]. Kultura - Społeczeństwo - Edukacja nr 2(12) 2017, Poznań 2017, pp. 105-128, Adam Mickiewicz University Press. ISSN 2300-0422. DOI 10.14746/kse.2017.12.5.
\end{abstract}

One can broadly divide research on higher education settings into three strands investigating 1) the production of specialized scientific knowledge, 2) the dynamics of institutional power (academic decision-making and governance), 3) teaching and learning. In all three areas the notion of 'discourse' has been salient in the last decades. However, the term is often understood differently by researchers from different fields, and the respective disciplines haven't always been receptive one to another. In the paper we present an overview of discursive approaches to the study of higher education in 1) social theory, poststructuralism in particular, and 2) linguistics. We explain the outlook on discourse which is prevalent in these areas and present the most significant studies on higher education contexts conducted within them. We argue that while social theory often lacks analytical detail and focus on empirical objects, linguistics on the other hand does not account for the way practices produce and reproduce social order.

Therefore, a study of academic discourse drawing on both strands would enable putting forward a robust theory and a precise methodology. In the last section of the paper we present an outline of such a field informed by both poststructuralism and pragmatics - Social Studies of Higher Education. 


\section{Wprowadzenie: dyskurs i badania szkolnictwa wyższego}

Sektor edukacji, a w szczególności szkolnictwo wyższe, rozbudowywał się w ciągu ostatnich stu pięćdziesięciu lat $\mathrm{w}$ niespotykanym tempie. Obecnie w wielu rozwiniętych państwach większość populacji na jakimś etapie życia korzysta z oferty szkół wyższych. Stały się one dla współczesnych społeczeństw ważne z wielu powodów: definiują w istotny sposób wartości i tożsamość niektórych grup społecznych, mają ogromne znaczenie dla gospodarki i są nierozłącznie związane $\mathrm{z}$ aktualnymi sposobami sprawowania władzy.

Termin „szkolnictwo wyższe” odnosi się nie tylko do jednego ze stopni edukacji. Często stosuje się go także jako synonim zbioru instytucji (w znaczeniu podobnym do wyrazu „akademia”), do określenia obszaru lub wspólnoty zawodowej („akademicy”) lub do pewnej praktyki („badania i nauczanie jako profesja”). W niniejszym tekście będziemy rozumieć pojęcie „szkolnictwo wyższe” w najszerszym możliwym sensie, w znaczeniu, jakie nadaje temu terminowi obszar Społecznych Badań Szkolnictwa Wyższego, ramy którego staramy się tutaj zarysować. To nowe pole bada zorganizowane praktyki społeczne w trzech obszarach:

1) tworzenie porządku społecznego przez akademików oraz uczestnictwo w zarządzaniu uczelnią („władza”);

2) produkcję wyspecjalizowanej wiedzy na poziomie instytucjonalnym („wiedza”);

3) praktyki uczenia się i nauczania („edukacja”).

Wymienione aspekty funkcjonowania szkolnictwa wyższego były analizowane w ramach różnych nurtów badawczych, które często pozostawały w relatywnej izolacji od pozostałych. Przykładowo: obszary wiedzy i władzy były obiektem zainteresowania nauk społecznych (socjologii, filozofii), ale także historii, zaś obszar edukacji był badany szczególnie przez pedagogów i lingwistów. We wszystkich tych nurtach jednak można zauważyć wzrost zainteresowania rolą języka w konstytuowaniu porządku społecznego, które z kolei przekłada się na zainteresowanie kategorią dyskursu w kontekście szkolnictwa wyższego. Argumentujemy, że tendencje te można opisać terminem "dyskursywny zwrot” i staramy się zebrać wszystkie reprezentujące je nurty w jedno pole o nazwie Społeczne Badania Szkolnictwa Wyższego. Pragniemy w ten sposób przedstawić spójną ramę dla dyskursywnych badań nad kontekstami akademickimi.

Do pojęcia dyskursu odwołują się coraz częściej badacze z rozmaitych dziedzin skupiających się na kontekstach akademickich (Hyland, 2009; Mulkay, Potter, Yearley, 1983: 1-19), lecz bywa ono rozumiane odmienne w ramach różnych kontekstów dyscyplinarnych. Choć najogólniej można rozumieć „dyskurs” jako spo- 
łeczną produkcję znaczenia, to w ramach szczegółowych badań wyłaniają się dwa paradygmaty: w tradycji „kontynentalnej” dyskurs oznacza ustrukturyzowaną przestrzeń znaczeń i wiedzy, do której odwołują się duże grupy ludzkie i populacje, natomiast w tradycji „,anglosaskiej” dyskurs jest usytuowaną praktyką społeczną jednostek lub grup, które wchodzą w interakcję za pośrednictwem szeroko rozumianego języka, często $\mathrm{w}$ celu negocjowania swoich tożsamości w określonych kontekstach (Angermuller, Maingueneau, Wodak, 2014: 2-3). Co ważne, podejścia z poziomu "makro" („strukturalistyczne”) oraz te z poziomu "mikro” nie powinny być postrzegane jako pozostające w ostrej opozycji do siebie nawzajem. Obie tradycje rozumieją dyskurs jako praktyki związane z mobilizowaniem semiotycznych i pozasemiotycznych narzędzi do angażowania się w praktyki społeczne oraz negocjowania społecznego, politycznego i kulturowego porządku. Istnieją jednak kwestie, w których tradycja kontynentalna i anglosaska mają odmienne stanowisko, co wpływa na proponowane przez nie metody.

Podejścia dyskursywne do wyższej edukacji są najczęściej kojarzone z wpływowymi pracami Michela Foucaulta (1972) dotyczącymi związku władzy i wiedzy. Nie powinniśmy jednak zapominać o innych, bardziej empirycznych perspektywach na badanie kontekstu akademickiego, takich jak nurty lingwistyczne, skupiające się na pragmatyce języka w użyciu, często w kontekście nauczania. Struktura niniejszego artykułu jest zatem następująca: zaczynamy od omówienia zastosowań teorii społecznej do analizy kontekstu szkolnictwa wyższego, skupiając się na poststrukturalizmie, ale omawiając także inne mikro- i makrosocjologiczne perspektywy patrzenia na procesy produkcji wiedzy i praktyki podejmowania decyzji w akademii; w sekcji poświęconej poststrukturalizmowi wprowadzamy teorię dyskursu; wskazując na kluczową rolę języka, omówimy rozmaite praktyki społeczne badaczy, ujmując je jako praktyki dyskursywne, które nie tylko odwzorowują, lecz także konstytuują społeczne ustrukturyzowaną przestrzeń akademii. Z punktu widzenia dyskursywnego pytanie brzmi: w jaki sposób tekst i mowa są używane $\mathrm{w}$ procesie konstruowania społecznego porządku w ramach instytucji szkolnictwa wyższego - zaczynając od porządku konstruowanego w obserwowalnych, usytuowanych praktykach pomiędzy akademikami, aż po określone, ustabilizowane, instytucjonalne hierarchie, które organizują duże akademickie populacje?

Podejścia teoretyczne są na ogół złożone na poziome konceptualnym, lecz problem dyskursu ujmują niejednokrotnie bez odniesienia do konkretnych tekstów i analizy danych. Aby więc uzupełnić tę lukę, w kolejnej części tekstu przechodzimy od dyskursywnych nurtów w ramach teorii społecznej (teoria dyskursu) do lingwistycznych metod badań nad dyskursem akademickim (analiza dyskursu) (Angermuller et al., 2014: 5-7). Metody te zostały w większości wypracowane 
w ramach pragmatyki językowej i skupiają się na analizie praktyk językowych na poziomie mikro. Pozwalają one lepiej zrozumieć zależne od kontekstu wzory komunikacji akademickiej (teoria rodzaju, retoryka nauki) oraz sposób, w jaki naukowcy budują swoją pozycję za pomocą językowych narzędzi (pozycjonowanie, analiza narracyjna). W ramach części poświęconej lingwistyce omówimy także Krytyczną Analizę Dyskursu (KAD) - metodę wyrosłą z dziedziny lingwistyki, lecz mającą znacznie szersze ambicje, jeśli chodzi o analizowanie kontekstu społecznego użycia języka, obecnie używaną przez specjalistów z innych dziedzin. Przedstawiamy KAD jako próbę pokonania rozziewu pomiędzy teorią społeczną a badaniami lingwistycznymi. Przekonujemy jednak, że nie powinna być postrzegana jako jedyne rozwiązanie powyższego problemu.

W trzeciej i ostatniej części próbujemy zebrać wszystkie powyższe nurty w nowe pole: Społeczne Badania Szkolnictwa Wyższego. Zarysowujemy ramy tego obszaru, obejmującego badania dyskursywnej konstrukcji porządku społecznego w wyższej edukacji jako przestrzeni, w której zachodzą na siebie pola wiedzy, władzy oraz edukacji. Ambicją Społecznych Badań Szkolnictwa Wyższego jest sproblematyzowanie języka jako teoretycznego i metodologicznego problemu w ramach badań szkolnictwa wyższego, ale także usunięcie rozziewu dzielącego obecnie dziedziny zajmujące się władzą, wiedzą i edukacją. Społeczne Badania Szkolnictwa Wyższego łączyłyby zatem teorię dyskursu $\mathrm{z}$ analizą dyskursu.

Niniejszy artykuł nie rości sobie pretensji do bycia wyczerpującym omówieniem dyskursywnych podejść do szkolnictwa wyższego. Za cel stawia sobie natomiast przedstawienie przystępnej panoramy owych badań, użytecznej dla wszystkich, którzy są zaintrygowani nową metodą badawczą i zagubieni w rozmaitych użyciach terminów „dyskurs” i „analiza dyskursu” tak w polu socjologii, jak i w zakresie dociekań filozoficznych oraz lingwistycznych. Refleksja nad rozumieniem samego terminu „dyskurs”, nad metodami, które mogą być wykorzystane do jego badania oraz ich teoretycznymi implikacjami, jest kluczowa, jeśli analiza dyskursu ma być poważnym przedsięwzięciem - w przeciwnym wypadku ryzykujemy, że termin „dyskurs” stanie się mętny, a co za tym idzie - nieprzydatny w badaniach (Antaki, Billig, Edwards, Potter, 2003; Van Dijk, 1990: 13-14). Badacze i badaczki powinni w pełni korzystać $\mathrm{z}$ istniejących badań i wypracowanych metod $\mathrm{w}$ interdyscyplinarnym duchu, który jest mile widziany we wspólnocie analizy dyskursu. Jednocześnie powinni jednak explicite definiować „dyskurs” i zdawać sprawę z metod użytych do jego studiowania, by uniknąć częstych oskarżeń o przecenianie implikacji badań lub o dobieranie danych tak, by potwierdzić z góry założoną tezę. Liczymy, że niniejszy tekst będzie przydatnym punktem odniesienia dla wszystkich, którzy planują przeprowadzić badania nad dyskursem w kontekście akademickim. 


\section{Teoria spoleczna i teoria dyskursu w badaniach szkolnictwa wyższego}

\section{Teoria społeczna}

Kwestie władzy i wiedzy w obszarze szkolnictwa wyższego są obecnie badane w ramach dwóch osobnych nurtów badawczych. Pierwszy koncentruje się na produkcji i reprodukcji wiedzy naukowej w społeczeństwach (np. Science and Technology Studies - STS), drugi zaś bada relacje władzy i nierówności, z którymi spotykają się aktorzy społeczni w organizacjach i w szerszym kontekście społecznym (np. Badania Szkolnictwa Wyższego - Higher Education Studies). Co więcej, owe nurty podzieliły się na odłamy skupiające się na analizie z poziomów mikro i makro, często pozostające w pewnej izolacji od siebie nawzajem.

W ramach badań skupiających się na wiedzy perspektywy makro koncentrują się na poziomie akademickich pól i wspólnot naukowych - co jest właściwe niektórym badaniom z zakresu historii idei oraz intelektualnej historii (Skinner, 1988), a także instytucjonalnym podejściom wpisującym się w dziedziny socjologii wiedzy i nauki (Maasen, Weingart, 2000; Merton, 1968) i teorii systemów (Luhmann, 1998). Perspektywy mikro natomiast przyglądają się usytuowanym praktykom produkcji wiedzy. Dobrym przykładem tego ostatniego są prace etnometodologów zaliczających się do nurtu Laboratory Studies (Knorr Cetina, 1981), z których wyłoniła się także teoria aktora-sieci (Latour, 1987). Do badań nad produkcją wiedzy przeprowadzanych z perspektywie mikro zaliczają się też prace z obszaru socjologii wiedzy (Lamont, 2009), niektóre spośród których skupiają się na aspekcie dyskursu (Ashmore, 1989; Gilbert, Mulkay, 1984; Hicks, Potter, 1991).

W obszarze „władzy” wymienić można prace dotyczące nierówności obserwowalnych na poziomie pól, a także całego społeczeństwa - na pierwszy plan wysuwają się tu badania Pierre’a Bourdieu (1988) dotyczące symbolicznej produkcji akademickiej. Możemy jednak również wskazać na neoinstytucjonalne badania dotyczące organizacji akademickich instytucji i systemów rozumianych jako „światy kulturowe” (world cultures) (Frank, Meyer, 2007). Podejścia z poziomu mezo i mikro odnoszą się natomiast do pytania, w jaki sposób dynamika władzy wyłania się i objawia w ramach akademickich organizacji. Nurty skupiające się na poziomie organizacji (poziom mezo) w ramach Badań Szkolnictwa Wyższego przyglądają się, w jaki sposób akademiccy aktorzy biorą udział w procesach decyzyjnych w zinstytucjonalizowanych przestrzeniach cechujących się organizacyjnymi zasadami (Musselin, 2009), zaś badacze kwestii wyboru skupiają się na zagadnieniu działania kolektywnego (Cohen, March, Olsen, 1972). 
Opisane powyżej nurty teoretyczne odzwierciedlają wielość idei i problemów, które rozważa współczesna szeroko rozumiana teoria społeczna. Wiele z wymienionych tu podejść zwraca uwagę na rolę procesów związanych ze społecznym wytwarzaniem znaczenia i komunikacją w obszarze szkolnictwa wyższego. Przykładowo, Bourdieu (1988) dowodzi, że struktury pola akademickiego są relacjami symbolicznymi (i na odwrót). Latour (1987) przypomina o roli technik inskrypcji w wytwarzaniu faktów naukowych. Frank i Meyer (2007) natomiast postrzegają instytucje akademickie, takie jak uniwersytet, jako przykład „świata kulturowego", który rozprzestrzenia się poprzez międzynarodową wymianę i komunikację. Jednak to właśnie poststrukturalizm wylansował tezę, że dyskurs musi być analizowany na własnych prawach, jako zorganizowana całość złożona z lingwistycznych i pozalingwistycznych praktyk społecznego wytwarzania znaczenia. Podejścia poststrukturalistyczne wyróżniają się tym, że kładą nacisk na skonstruowany charakter porządku społecznego. Porządek społeczny nie jest zatem bezpośrednio postrzeganą rzeczywistością, którą język po prostu reprezentuje, wyraża lub odzwierciedla - wyłania się on z praktyk dyskursywnych, ale jednocześnie kształtuje owe praktyki.

\section{Dyskurs w teorii poststrukturalistycznej}

Wyłonienie się dyskursu jako kategorii analizy związane jest ze zwrotem lingwistycznym w powojennej teorii społecznej i politycznej (Angermuller, 2015; Angermuller et al., 2014). Zainteresowanie dyskursem było kluczowe dla wielu interdyscyplinarnych debat, w których, czerpiąc z teorii języka (jak strukturalizm Saussure'a czy pragmatyka Wittgensteina), definiowano na nowo teoretyczne koncepty, takie jak „aktor społeczny”, „praktyka”, „władza” czy „społeczeństwo”. Do symptomów zwrotu lingwistycznego można zaliczyć tak różnorodne tradycje, jak fenomenologia Heideggera czy etyka dyskursu Habermasa. Najbardziej znaną etykietką jest jednak poststrukturalizm, kojarzony na pierwszym miejscu z teoretykami z Francji, przede wszystkim z Michelem Foucaultem.

Dla poststrukturalistów dyskurs pełni funkcję konstytutywną w procesach wytwarzania znaczenia w ramach społeczeństwa. Nie odzwierciedla on żadnej prawdy ani rzeczywistości, nie wyraża też intencji aktorów. Przyglądając się dyskursowi, możemy natomiast szukać odpowiedzi na pytanie: „co uznawane jest za prawdziwe i realne?, a także kto jest uznawany za 'realny' podmiot?. Poststrukturalizm odcina się tak od pozytywizmu, jak i od humanizmu, twierdząc, że język nie tylko reprezentuje społeczny i polityczny porządek, ale że, reprezentując, jednocześnie je konstruuje. 


\section{Foucaultowski poststrukturalizm a badania szkolnictwa wyższego}

Choć „zwrot dyskursywny” można zaobserwować w wielu dyscyplinach związanych z badaniem szkolnictwa wyższego, to Foucaultowski poststrukturalizm niejako zbiera w całość dwa wyżej wspomniane obszary badań nad akademickimi praktykami, analizując władzę łacznie z produkcją wiedzy. Inspirowane tekstami Foucaulta rozumienie dyskursu jako wiedzy-władzy przeniknęło do debaty w ramach teorii społecznej, a co za tym idzie, także do badań nad szkolnictwem wyższym (Angermuller, 2012). Z punktu widzenia teorii Michela Foucaulta edukacja wyższa jest społecznie ustrukturyzowaną przestrzenią, konstytuowaną przez praktyki dyskursywne akademików, którzy poprzez używanie języka zajmują pozycje określonych podmiotów (subject positions).

Foucault pisze o specjalistycznej, wytwarzanej społecznie wiedzy, która krąży w danym społeczeństwie w określonym historycznie momencie i która legitymizuje „rządomyślność” (governmentality). Termin ten oznacza reżim złożony $\mathrm{z}$ dyskursywnych i niedyskursywnych mikropraktyk rządzenia poprzez monitorowanie i kontrolowanie dużych populacji. Pojęcie „rządomyślności”, ale także inne wprowadzone przez Foucaulta, takie jak dyspozytyw (dispositif), technologia władzy (government technology) i techniki siebie (technologies of the self), są obecnie często używane w analizowaniu kwestii neoliberalizmu (Angermuller, 2010). W związku ze strukturalnymi przemianami instytucji akademickich i związanymi $\mathrm{z}$ nimi zmianami w naturze pracy akademickiej, często zbiorczo określanymi mianem „akademickiego kapitalizmu” (Münch, 2014), pojawia się coraz więcej badań skupiających się na problemie zarządzania akademickim podmiotem (governance of the academic subject). Biorąc przykład $\mathrm{z}$ badaczy, którzy przeprowadzili analizy praktyk rządomyślności w obszarach takich jak zdrowie psychiczne (Rose, 1999) czy pedagogika i polityka edukacyjna (Ball, 1990, 2013; Masschelein, 2007; Peters, Olssen, 2009), badacze i badaczki zaczęli przyglądać się uważnie działaniu rządomyślności w ich własnym środowisku, czyli akademii. Jedna z pierwszych analiz przemian w strukturach szkolnictwa wyższego wyrażonych w Foucaultowskim „języku” ukazywała techniki kontroli akademików jako tylko jeden z wielu przykładów działania „społeczeństwa audytu” (Power, 1997). Kolejne badania w tym nurcie skupiały się już wąsko na praktykach rządomyślności w akademii, na przykład na procesach "upodmiotowienia” (subjectification) oraz zarządzania akademickim „ja” (Davies \& Bansel, 2010; Gill, 2009). Choć nie wszystkie badania nad rządomyślnością odwołują się explicite do metody analizy dyskursu, to na ogół bazują na specyficznym Foucaultowskim rozumieniu porządku społecznego, w którym dyskurs odgrywa ważną rolę. 
Wprowadzenie neoliberalnych technologii zarządzania do sfery akademickiej oznacza także wzrost tendencji do reprezentowania relacji społecznych poprzez kody numeryczne, takie jak liczby, wskaźniki i rankingi. Używanie rankingów instytucji, statystyk cytowań, a także różnych form oceny parametrycznej do monitorowania i kontrolowania społeczności akademickiej można opisać w kategoriach „akademickiej rządomyślności” (Angermuller, 2017; Angermuller, Maeße, 2015). Tymczasem, na podstawie wywiadów przeprowadzonych z badaczami, Angermuller (2013a) wykazuje, jak różni się lektura tekstu przez człowieka od „czytania”, jakie może wykonać komputer, działający na podstawie procedury liczenia. Choć oba typy „lektury” prowadzą do wytworzenia pewnej reprezentacji akademickiej rzeczywistości, która może być opisana jako „prawdziwa”, to reprezentacje wykonane przez maszyny nie będą odzwierciedlać relacji pomiędzy badaczami takimi, jakimi są one postrzegane przez ludzi. Przykładowo, badacz może odnosić się do czyjegoś tekstu bez podawania nazwiska autora, a jego ludzki czytelnik rozpozna odniesienia, które nie są wyrażone explicite (np. wiele tekstów poststrukturalistycznych odnosi się implicite do tekstów Foucaulta).

Choć w tekstach poststrukturalistycznych podkreśla się często kluczową rolę języka, to konkretne analityczne orientacje czy empiryczne metody pozostają niejednokrotnie w sferze niedopowiedzeń. $\mathrm{W}$ debacie nad poststrukturalizmem język pozostawał często metaforą praktyk związanych $\mathrm{z}$ wytwarzaniem znaczenia i komunikacją. Wielu lingwistów uważa w związku z tym, że poststrukturalizm lubuje się w mętnych teoriach i poświęca zbyt wiele uwagi refleksji nad własnymi roszczeniami do prawdy. Lingwistom często trudno jest zrozumieć, czym byłby „dyskurs”, niezwiązany z użyciem języka w konkretnych kontekstach. Istotnie, wielu badaczy i badaczek odwołujących się do myśli Foucaulta nie opiera się w swoich dociekaniach na bliskim czytaniu i analizie tekstów. Zamiast na warstwie lingwistycznej, skupiają się oni na treści, którą łączą z szerszym instytucjonalnym kontekstem, oraz na ogólnych tendencjach dostrzegalnych w zbiorach tekstów.

Nie moglibyśmy jednak mówić o zwrocie dyskursywnym w badaniach nad szkolnictwem wyższym, gdyby nie istniały solidne ramy do systematycznych refleksji nad zjawiskami lingwistycznymi. Innymi słowy, by zwrot dyskursywny w szkolnictwie wyższym mógł naprawdę zaistnieć, ramy teoretyczne muszą zostać połączone z metodologią analizy dyskursu, co pozwoli systematycznie opisać społeczne użycie języka. W kolejnej części artykułu wskażemy zatem na analityczne podejścia do dyskursu, wywodzące się na ogół z obszaru lingwistyki, i pokażemy, w jaki sposób mogą one być użyte do empirycznej analizy obiektów dyskursywnych w kontekście szkolnictwa wyższego. Omówimy też metodę zakorzenioną w lingwistyce, lecz biorącą pod uwagę znacznie szerszy kontekst społeczny - Krytyczną Analizę Dyskursu (KAD). 


\section{Lingwistyczne podejścia do dyskursu w kontekście szkolnictwa wyższego}

Spośród trzech pól, które wcześniej wymieniliśmy jako składające się na obszar szkolnictwa wyższego - wiedza (badania prowadzone w ramach dyscyplin), władza (procesy decyzyjne i zarządzanie) oraz nauczanie (procesy uczenia i uczenia się) - lingwiści skupiali się przede wszystkim na tym ostatnim. W ostatnich dekadach nastąpił znaczący wzrost liczby badań nad użyciem języka w kontekście edukacji, w obszarach takich jak pedagogika, badania nad edukacją czy poszczególne filologie (np. romanistyka, germanistyka etc.), a także w stosunkowo nowych polach związanych z nauczaniem języka angielskiego - English for Specific Purposes (ESP) i English for Academic Purposes (EAP). Do tematów, którym przyglądają się badacze i badaczki, należą: procesy uczenia się języka, tworzenie i udoskonalanie materiałów do nauczania języków, ewaluacja postępów studentów czy interakcje w klasie (classroom discourse) (eg. Coulthard, 1992; Garton, Richards, 2008; Hyland, Shaw, 2016; Lemke, 1992; Sinclair, Coulthard, 1981). Badania te stawiają przed sobą cele przede wszystkim pedagogiczne, związane ze skutecznością nauczania. Jako takie, nie podejmują na ogół bezpośrednio kwestii porządku społecznego, władzy czy nierówności - a więc nie łączą się bezpośrednio z praktykami dyskursywnymi w edukacji wyższej, takimi, jakimi ujmujemy je w tym tekście. Nie będziemy ich zatem omawiać tutaj szczegółowo. Warto jednak zwrócić uwagę, że badania nad uczeniem i nauczaniem zaczynają coraz częściej czerpać z teorii społecznej - jest to widoczne w zainteresowaniu relacją pomiędzy praktykami nauczania a kontekstem, w jakim się ono odbywa, co obejmuje kwestie kultury, klasowości i ideologii (Gee, 2015; Popow, 2016).

$\mathrm{W}$ tej sekcji omawiamy różne metodologiczne podejścia do analizowania danych językowych - są to w większości metodologie należące do obszaru lingwistyki, ale czerpiące niejednokrotnie z dyscypliny filozofii, historii czy jakościowych nurtów w ramach psychologii i socjologii. Postaramy się zatem pokazać użyteczność teorii gatunków tekstu (genre theory), retoryki nauki (rhetoric of science), teorii pozycjonowania (positioning theory) i analizy narracyjnej (narrative analysis) w badaniach szkolnictwa wyższego. Wiele z tych metod można zaliczyć do szerszej kategorii badań pragmatycznych.

Pragmatyka pojawiła się jako reakcja na strukturalistyczną lingwistykę Saussure’a. Pragmatyści nie byli zainteresowani badaniem znaków jako elementów całości struktury langue, ale tym, jak znaczenia powstają w specyficznych kontekstach (parole) oraz sposobami, w jakie praktyki społeczne są realizowane poprzez semiotyczny repertuar komunikujących się osób. Odrzucając normatywne podej- 
ście do języka - często utożsamiane z lingwistyką uprawianą w duchu Saussure’a zgodnie z którą język jest przede wszystkim systemem gramatycznym, pragmatyści skupiają się na negocjacji potencjału znaczeniowego przez osoby używające języka w określonym kontekście (Thomas, 2013: 1-2).

\section{Gatunek tekstu (genre)}

Angielskie pojęcie genre tłumaczymy tutaj jako gatunek (tekstu), choć można je także przełożyć jako „rodzaj literacki” (np. w tytule czasopisma naukowego „Zagadnienia Rodzajów Literackich", wydawanego na Uniwersytecie Łódzkim). Pojawia się też pojęcie analizy genologicznej (jako tłumaczenie terminu genre analysis). Pojęcie "gatunek" odnosi się do klasy wydarzeń komunikacyjnych nastawionych na wspólny cel, uznawany przez członków danej wspólnoty (Swales, 1990: 58). U podstawy wielu badań z zakresu analizy gatunków leży założenie, że istnieją „wspólnoty dyskursywne” (discourse communities) - szeroko rozumiane grupy społeczno-retoryczne (znaczenie terminu omawia Swales, 1998: 20-23), które wytwarzają wzorce komunikacji ustnej i pisemnej, służące określonym celom komunikacyjnym grupy. Ważną funkcją gatunku jest wzmacnianie spójności wspólnoty dyskursywnej. Przykładowo, przedstawiciele danego zawodu będą porozumiewać się za pomocą znanych im gatunków - takich jak wizytówka, notka biograficzna, prezentacja naukowa, email zawodowy - których znajomość pozwala im rozróżniać członków grupy od outsiderów.

Badacze i badaczki dyskursu akademickiego przyglądali się regułom rządzącym gatunkami akademickimi (Swales, 1990), różnicom w nich zależnym od dyscyplinarnego lub narodowego kontekstu (Hyland, 2009), ich rozwojowi we współczesnym kontekście umiędzynarodowienia i hybrydyzacji (Duszak, Kowalski, 2015) oraz procesowi uczenia się/nabywania biegłości w używaniu gatunków (Hyland, Hyland, 2006). Najdokładniej zbadanym gatunkiem tekstu akademickiego jest artykuł naukowy (Myers, 1989; Swales, 2011), lecz badacze przyglądali się także studenckim esejom (Nesi, Gardner, 2012), aplikacjom o granty (Myers, 1985), patentom (Myers, 1995). Najczęściej badane są, jak widać, gatunki pisane, lecz można zaobserwować też wzrost zainteresowania gatunkami mówionymi i mieszanymi, takimi jak prezentacja akademicka (Reershemius, 2012) czy obrona pracy dyplomowej (Maingueneau, 2002).

Do badanych aspektów gatunku należą między innymi makrostruktura tekstu i typowe jednostki funkcjonalne w tekście, czyli tak zwane „kroki” (moves), dominujące formy gramatyczne (np. nominalizacja lub werbalizacja), oceny wartościujące (appraisal markers), ton, styl, użycie metafory, środków retorycznych czy hu- 
moru, taktyki grzecznościowe, częstotliwość występowania poszczególnych słów lub zbitek leksykalnych etc. Badania nad gatunkami coraz częściej wykorzystują narzędzia korpusowe (w tym wsparte komputerowo) umożliwiające analizowanie większych zestawów danych (np. Nesi, Gardner, 2012; Reershemius, 2012). Na poziomie teorii badania nad gatunkami nie czerpią jedynie z klasycznej pragmatyki, ale także z lingwistyki kognitywnej, semiotyki, lingwistyki systemowo-funkcjonalnej Hallidaya, a nawet z obszarów takich jak socjologia wiedzy (Myers, 1990) czy Foucaultowska analiza dyskursu (Porter, 1992).

Część badań z zakresu gatunków akademickich stawia przed sobą cel wyraźnie edukacyjny. Mają one mianowicie stanowić pomoc dla nowych członków wspólnoty dyskursywnej, którzy dopiero nabywają biegłość w używaniu gatunków, oraz dla nauczycieli, którzy wprowadzają nowicjuszy w tajniki gatunków (Flowerdew, 1993; Nesi, Gardner, 2012). Przykładowo, wypracowany przez Swalesa (1990) model pisania abstraktów akademickich artykułów stał się klasycznym punktem odniesienia $\mathrm{i}$ jest szeroko nauczany na kursach akademickiego pisania. Takie jego zastosowanie może skłonić do refleksji nad tym, jak nauczanie zasad rządzących gatunkami może wpłynąć na ich rozwój - przykładowo doprowadzając do usztywnienia ram gatunku.

Wychodząc od klasycznej definicji gatunku - klasa wydarzeń komunikacyjnych nastawionych na wspólny cel (Swales, 1990: 68) - możemy skupić się właśnie na celach, jakie dana wspólnota stawia przed sobą i którym daje wyraz, używając określonych gatunków. Takie pytanie wyprowadzi nas poza obręb pedagogicznych zastosowań analizy gatunków, w kierunku rozważań związanych z wartościami i normami. Możemy zatem postrzegać gatunki tekstu nie tylko jako odzwierciedlające cele i wartości określonej grupy, lecz także jako element, który je kształtuje. W tym duchu Bhatia (1993) zaproponował rozbudowanie analizy gatunku o wywiady z autorami, które pomogłyby dodać do analizy kolejny poziom, dający pojęcie o instytucjonalnych uwarunkowaniach powstawania gatunku. W swoich późniejszych tekstach Swales (1998) poszedł krok dalej na tej samej drodze, wypracowując metodę „tekstografii”. Jego przykład analizy akademickich gatunków wytwarzanych w jednym budynku uniwersyteckim uwzględniał etnograficzne badanie szerokiego kontekstu, w którym powstają teksty. Analiza obejmowała zatem nie tylko same teksty należące do danych gatunków, ale także ich materialne medium (np. papier, medium elektroniczne), uwarunkowania przestrzenne (wygląd i umeblowanie pomieszczenia, w którym powstaje tekst), obserwację samego procesu pisania oraz wywiady z autor(k)ami. To tylko jeden przykład analizy gatunku akademickiego tekstu, którego cele wykraczają daleko poza pedagogikę i wchodzą w obręb zainteresowań teorii społecznej. 


\section{Retoryka nauki}

Kolejnym podejściem, które skupia się na dokładnym badaniu właściwości tekstu, jest retoryka nauki. Choć pytania, na jakie próbują odpowiedzieć retorycy zajmujący się komunikacją akademicką, są często podobne do tych zadawanych przez badaczy gatunków, to retoryka skupia się przede wszystkim na aspekcie perswazji. Keith i Rehg (2009: 211) twierdzą, że retoryka nauki pojawiła się na przecięciu teorii argumentacji i społecznych badań nad nauką (Science Studies). Z pewnością wyłoniła się ona w kontekście „zwrotu retorycznego” i założenia szkoły tak zwanej „nowej retoryki” (Rehg, 2009) w badaniach nad argumentacją (Perelman, Olbrechts-Tyteca, 1969). Zwrot retoryczny spowodował przeniesienie zainteresowania retoryków z modeli argumentacji i stojącej za nimi logiki w kierunku argumentacji, która odbywa się w specyficznych, realnych kontekstach. Zaczęto zadawać pytania o to, jak argumentacja zmienia się w zależności od publiczności, do której jest skierowana, dlaczego argumenty kontrfaktyczne mogą wciąż być perswazyjne etc. To z kolei zainspirowało badania nad komunikacją naukową, którą dotąd postrzegano jako nieretoryczną (Rehg, 2009: 21).

Choć tradycja retoryczna wydała wiele dzieł skupiających się na ocenie strategii retorycznych autorów akademickich, a także radach dotyczących zwiększenia perswazyjności ich tekstów (np. Fahnestock, 1999), tutaj bardziej interesują nas badania, które łączą retoryczny aspekt tekstów z ich instytucjonalnym, historycznym i dyscyplinarnym kontekstem. Za kamień węgielny retoryki nauki uprawianej w tym duchu uznawana jest przez wielu książka Charlesa Bazermana Shaping Written Knowledge (1988). Autor bada w niej - opierając się na korpusie ponad 160 tekstów - rozwój przez wieki gatunku eksperymentalnego artykułu naukowego. Łączy on jego powstanie z szerszym kontekstem - społecznymi i politycznymi wydarzeniami, które mają wpływ na to, jak akademicy piszą. Podejście Bazermana do analizy tekstów naukowych jest interdyscyplinarne - czepie on ze społecznych badań nad nauką, filozofii nauki i psychologii.

W The Rhetoric of Science Alana Grossa (1990) - kolejnym ważnym dziele w obszarze retoryki nauki - autor analizuje kluczowe wydarzenia w historii nauki (zwrot kopernikański, teoria ewolucji Darwina, odkrycie DNA), przyglądając się im z punktu widzenia retoryki. Gross twierdzi, że wybranie odpowiednich z punktu widzenia retoryki argumentów we właściwym momencie historii może mieć wpływ na (lub nawet całkiem zdeterminować) odbiór teorii naukowej. Kolejna książka Grossa i współpracowników (2002) skupia się na zmianach w kształcie gatunku artykułu naukowego w pięciu dziedzinach, w trzech językach i na przestrzeni aż czterech wieków. Autorzy zwracają uwagę na uwarunkowanie tych 
zmian przez zewnętrzne okoliczności historyczne, takie jak postępująca specjalizacja czytelników, poszerzająca się przepaść między teoretycznymi i aplikowanymi badaniami, pojawienie się ściślej określonych naukowych standardów etc. Roy Harris (2007) prześledził historyczne wyłonienie się samego terminu „nauka” jako metakonceptu i kategorii, przyglądając mu się przez pryzmat semantyki i filozofii języka. Jego badania pokazują, jak przez wieki zmieniało się znaczenie „uprawiania nauki” - wpływały na to przemiany społeczne, ale także normatywne działania instytucji takich jak Royal Society. Wreszcie McCloskey (2009) skupia się na polu ekonomii, pokazując, że, wbrew powszechnej opinii, teksty ekonomiczne nie są suche i pozbawione literackich walorów, lecz przeciwnie - obfitują w metafory, symetrię i inne elementy perswazyjne. Autorka argumentuje, że świadome zastosowanie retoryki w pisaniu tekstów ekonomicznych może pomóc odnowić dyscyplinę, wyprowadzając ją poza modernistyczny, ilościowy paradygmat.

Badania z zakresu retoryki nauki przypominają analizę gatunków pod względem metod i celów badawczych, na ogół przyjmują jednak szerszą historyczną perspektywę i łączą zmiany w języku z procesami społecznymi i instytucjonalnymi. Większość specjalistów w zakresie retoryki nie posługuje się pojęciem „dyskursu” czy „analizy dyskursu”. Ich badania różnią się od analizy dyskursu pod dwoma względami: retorycy na ogół stawiają sobie praktyczne, pedagogiczne cele (lepsze stosowanie argumentacji w debatach), zaś język postrzegają jako narzędzie do osiągania celów (w historycznie uwarunkowanych sytuacjach), nie zaś jako społeczny problem lub aspekt relacji społecznych, jak w teorii dyskursu.

\section{Teoria pozycjonowania i podmiotowość}

Pozycjonowanie to fenomen wpierw opisany przez psychologów społecznych (Harré, Van Langenhove, 1999) czerpiących z jakościowych badań w podejściu interakcyjnym oraz z poststrukturalizmu. Badacze pozycjonowania poszukują odpowiedzi na pytanie: w jaki sposób ludzie negocjują swoje pozycje przez język (pisany lub mówiony)? Podejście to jest związane z teorią Austina (1962), która postrzega akty mowy nie tylko jako komunikaty, ale także jako performatywy: nie tylko przekazują one informacje, ale także robią coś.

Propozycja Angermullera wpisuje się w nurt interakcyjny - opisuje ona dyskurs jako praktykę pozycjonowania (Angermuller, 2013b) i jednocześnie czerpie $\mathrm{z}$ teorii poststrukturalistycznych, które przedstawiają podmiot jako dyskursywny efekt języka. Angermuller proponuje teorię enuncjacji (enunciation theory), którą opisuje jako „francuską wersję pragmatyki językowej” (Angermuller, 2014), pozostającą jednak pod wpływem poststrukturalizmu. Teoria enuncjacji analizuje, 
w jaki sposób pozycje podmiotów (subject positions) są konstruowane za pomocą językowych narzędzi deixis (procesy, w których znaczenia wyrazów powstają w kontekście) oraz polifonii (wielogłosowości, także w wypowiedzi pojedynczego aktora). Dyskurs postrzegany jest jako dialogiczna przestrzeń komunikacji, w której wiele głosów współwystępuje w ramach wypowiedzi. Najmniejsza konstytutywna jednostka dyskursu - wypowiedź (utterance) - zawiera w sobie liczne głosy i perspektywy - zawsze odnosi się do „lokutora”, czyli autora, zaś przez znaczniki polifonii (takie jak wyraz „nie”) może aktywować wiele innych głosów lub „enuncjatorów". Ducrot (2014) tłumaczy zjawisko polifonii w wypowiedzi na przykładzie zdania „ściana nie jest biała”, przez co pokazuje, że nawet tak proste wyrażenie nie wyraża jedynie punktu widzenia jednego autora. Przeciwnie - pokazuje polifoniczny układ wielu głosów. W tym przykładzie lokutor tego zdania reprezentuje głos (lokutor L), który odrzuca inny głos (allokutor A), twierdzący, że ściana jest biała. Zaprzeczenie „nie” informuje zatem czytelników o odmiennych perspektywach lokutora i allokutora. Ten przykład uzasadnia twierdzenie, że negacja jest polifoniczną operacją. Możemy wskazać wiele podobnych zjawisk występujących wszędzie tam, gdzie wypowiedzi używane są w społecznym kontekście - są one widoczne w zabiegach takich jak cytowanie, ale także w cechach tekstu, jak intonacja, układ etc. Podsumowując, można stwierdzić, że enuncjatywna analiza dyskursu stawia sobie za cel ujawnienie mechanizmów kontekstualizacji wypowiedzi, wskazanie na wielość głosów obecnych w dyskursie i pokazanie, jak konstruowane są ich „podmioty”.

Zastosowana do kontekstu szkolnictwa wyższego enuncjatywna analiza dyskursu oraz teoria pozycjonowania jako metodologie pokazują, w jaki sposób spolecznie skonstruowane pozycje podmiotów oraz porządek społeczny są tworzone, wyrażane i podtrzymywane poprzez użycie tekstu i mowy. Baert (2012) stosuje pojęcie pozycjonowania do analizy działalności publikacyjnej akademików jako próby zajęcia określonej pozycji w polu intelektualnym, ale także przypisania określonych pozycji innym intelektualistom jako stronnikom, mentorom, oponentom. Angermuller użył teorii enuncjacji do opisania dialogicznej natury akademickiego dyskursu i pokazał, w jaki sposób intelektualne podmiotowości są tworzone oraz dekonstruowane w podstawowych tekstach francuskiego strukturalizmu (Angermuller, 2014). Można jednak przyjąć bardziej socjologiczne spojrzenie na akademickich aktorów i przyjrzeć się, jak tekst i mowa są używane przez akademików do negocjowania wartości akademickich pozycji oraz produkowania i reprodukowania społecznych hierarchii wśród badaczy (Angermuller, 2013b; 2017).

Akademickie biografie, w tym konstruowanie i negocjacja pozycji podmiotu, są kwestią, który badała nie tylko teoria pozycjonowania, ale także analiza nar- 
racyjna (narrative analysis) - te dwa podejścia są zresztą niekiedy łączone (Bamberg, 1997; 2010). Analiza narracyjna bada, w jaki sposób ludzie za pomocą tekstu i mowy umieszczają swoją własną rolę (np. zawodową, rodzinną etc.) w szerszym społecznym kontekście. Badacze pytają na przykład, z jakich repertuarów (takich jak większe narracje lub fabuły popularne w danej kulturze) czerpią mówiący i w jaki sposób pozycjonują się (lub są pozycjonowani) w obrębie swojego pola, a także w stosunku do innych podmiotów. W obszarze szkolnictwa wyższego Neil Gross (Gross, 2002) wykorzystuje analizę narracyjną do przyjrzenia się korpusowi wywiadów z amerykańskimi filozofami z obszaru pragmatyki, by zbadać pojęcia, których ci używają w opisywaniu swojej własnej roli. Ylijoki (2005) skupia się na zjawisku „nostalgii za złotym wiekiem”, pojawiającym się w korpusie wywiadów z badaczami, zaś Haman (2015) przygląda się nekrologom akademików, pokazując, w jaki sposób ich biografie są pośmiertnie „konsekrowane” przez innych. Ten nurt badawczy, podobnie jak retoryka nauki, wychodzi poza analizę języka w indywidualnych interakcjach, często wkraczając w obszar teorii społecznej, na przykład wtedy, gdy rozważane jest pytanie o to, dlaczego określone rodzaje narracji się przebijają, podczas gdy inne są uciszane.

\section{Łq̨czenie teorii społecznej i perspektyw lingwistycznych - od teorii do analizy dyskursu}

Akademicy uczestniczą jednocześnie w praktykach społecznych należących do obszaru wiedzy, władzy i edukacji. By objąć je w ramach badań dyskursywnych, należy połączyć teorię dyskursu z analizą dyskursu. Teorie dyskursu próbują opisać społeczne, polityczne, ekonomiczne i kulturowe siły, które kształtują porządek społeczny szkolnictwa wyższego (przykład mogą stanowić Foucaultowskie pojęcia rządomyślności i technik siebie). Analiza dyskursu natomiast obejmuje analityczne narzędzia i metody, które opisują społeczne użycie tekstu i mowy (tak jak teoria aktów mowy, analiza gatunków, analiza narracyjna etc.). Artykuły z zakresu teorii dyskursu są bogate, jeśli chodzi o poziom konceptualny, lecz relatywnie oderwane od konkretnych danych (lub też związek z określonymi tekstami nie jest opisany explicite). W ramach analizy dyskursu natomiast, szczególnie tej wpisującej się w tradycję pragmatyczną, można dostrzec skupienie na analizie w skali mikro małych zestawów danych, które nie pozwalają na wyciąganie szerszych konkluzji. Coraz popularniejsze jest łączenie teoretycznych i analitycznych perspektyw, co pozwala na wykorzystanie mocnych stron obydwu podejść i przezwyciężenie ich słabości. Przykład może stanowić połączenie teorii rządomyślności oraz teorii 
enuncjacji, zastosowane do analizy reżimu władzy/wiedzy w wyższej edukacji (Angermuller, 2010). W kolejnej sekcji skupimy się na zastosowaniu do badań szkolnictwa wyższego Krytycznej Analizy Dyskursu (KAD), które można postrzegać jako próbę pokonania rozziewu pomiędzy analizą na poziomie mikro i makro, pomiędzy teorią dyskursu a jego analizą.

\section{Krytyczna Analiza Dyskursu (KAD)}

Krytyczna Analiza Dyskursu (KAD) jest często explicite prezentowana jako próba połączenia empirycznie zorientowanych badań lingwistycznych z szerszą perspektywą społeczną (Fairclough, 1993: 134; Van Dijk, 1990: 10). Badania w tym obszarze skupiają się na relacji między językiem a władzą, ideologią i nierównościami. KAD ma swoje korzenie w ruchu lingwistyki krytycznej z lat siedemdziesiątych XX wieku, który zapoczątkowali badacze tacy jak Fowler, Kress, Hodge i Trew (1979), skupiający się na związku między władzą a ideologią. KAD czerpie też z lingwistyki systemowo-funkcjonalnej Hallidaya oraz, do pewnego stopnia, $\mathrm{z}$ teorii marksizmu i teorii krytycznej w tym zakresie, w jakim za cel stawia sobie stworzenie lepszego, bardziej równego społeczeństwa. Projekty badawcze wpisujące się w KAD zwykle przedstawiają, jak sama nazwa wskazuje, krytyczny głos - stanowią próbę interwencji. Co się z tym łączy, tego rodzaju badania przyjmują zwykle pewien zestaw założeń związanych $\mathrm{z}$ naturą władzy oraz dyskursu. A mianowicie, zakładają, że dyskurs jest usytuowaną społecznie praktyką, która jest jednocześnie społecznie kształtowana, ale też społecznie kształtująca - konstytuuje ona społeczną rzeczywistość, wraz z relacjami społecznymi, tożsamościami oraz systemami wiedzy i wierzeń (Fairclough, 1993: 134).

Norman Fairclough, jeden z najbardziej znanych teoretyków nurtu KAD, już w 1993 roku opublikował pierwsze refleksje nad związkiem języka i władzy w akademii. W badaniu dotyczącym procesów urynkowienia uniwersytetów w Wielkiej Brytanii przyjrzał się on przemianom w akademickim dyskursie na podstawie korpusu złożonego z uniwersyteckich prospektów, ogłoszeń o pracę dla badaczy, promocyjnych materiałów konferencyjnych oraz przykładu akademickiego CV (swojego własnego!). Jego analiza pokazuje, w jaki sposób język stał się istotnym narzędziem do osiągania komercyjnych celów w ramach szkolnictwa wyższego. Jest to widoczne w nowych praktykach promowania uniwersytetów jako prężnych ośrodków badań i nauczania, ale także w autopromocji poszczególnych badaczy. Tym zmianom towarzyszy „technologizacja dyskursu” - proces aktywnego wpływania przez instytucję na istniejące praktyki dyskursywne i projektowania ich na nowo zgodnie z zasadami instytucjonalnej efektywności. Do przykładów takiego działania można zaliczyć 
szkolenia przygotowujące badaczy, by komunikowali się zgodnie z pewnymi kanonami, często zaczerpniętymi z gatunków związanych z marketingiem i nastawionych na podkreślenie aspektów związanych z przedsiębiorczością. W związku z tymi tendencjami stare akademickie praktyki i gatunki są „kolonizowane” przez gatunki związane z promocją i reklamą, co prowadzi do „hybrydyzacji” różnych porządków dyskursu (przykładowo akademickie CV nie pełnią już tylko funkcji informacyjnej, lecz mają też „sprzedawać” umiejętności właściciela/właścicielki). Te obserwacje, poparte empiryczną lingwistyczną analizą, Fairclough zamyka refleksjami natury ogólnej dotyczącymi zmian w akademii. Dotyczą one autorytetu instytucji, który nie jest już „oczywisty”, lecz musi być nieustannie konstytuowany na nowo poprzez użycie dyskursu, oraz tożsamości badaczy, które stają się obiektem zabiegów związanych z autopromocją. Fairclough zamyka tekst uwagą dotyczącą użyteczności KAD-u nie tylko do analizy obecnego stanu rzeczy, lecz także do aktywnego zmieniania dyskursu w kierunku, który odchodziłby od dawnych wzorców, lecz jednocześnie nie kopiował rynkowych, promocyjnych form.

Fairclough powrócił do tematu dyskursu we współczesnym (neoliberalnym) szkolnictwie wyższym w 2003 roku w wykładzie, który podejmował z grubsza ten sam problem, co tekst sprzed dwudziestu lat, lecz tym razem bez szczegółowej analizy danych. Wraz z socjologiem polityki Bobem Jessopem oraz lingwistką Ruth Wodak Fairclough zaproponował nową metodę, która umożliwiłaby interdyscyplinarne badania nad zmianą społeczną, biorąc pod uwagę jej aspekty semiotyczne (związane z wytwarzaniem znaczenia). Koncepcja ta, nosząca nazwę Krytycznej Ekonomii Politycznej (Critical Political Economy), łączy „regulacyjne podejście do politycznej ekonomii, teorię społeczną Gramsciego oraz krytyczną analizę dyskursu" (Fairclough, 2007: 133). Z wprowadzeniem Krytycznej Ekonomii Politycznej Krytyczna Analiza Dyskursu, która już na wstępie była interdyscyplinarnym podejściem, została włączona w rozbudowaną ramę stworzoną z myślą o analizie procesów socjoekonomicznych - być może adekwatną do badania złożonej i wielowymiarowej rzeczywistości umiędzynarodowionej akademii w gospodarce opartej na wiedzy (Jessop, Fairclough, Wodak, 2008).

$\mathrm{KAD}$, podobnie jak poststrukturalistyczna analiza dyskursu, bada dyskurs u zbiegu obszarów związanych z językiem i społeczeństwem - te dwa podejścia różnią się jednak w wielu punktach. Poststrukturalizm jest osadzonym w teorii społecznej, politycznej i kulturowej symptomem „zwrotu lingwistycznego”, który zwrócił uwagę badaczy spoza obszaru lingwistyki na problemy związane z językiem. KAD tymczasem został zapoczątkowany właśnie przez lingwistów, którzy zainteresowali się szerszym społecznym kontekstem, w jakim używany jest język. Podejścia poststrukturalistyczne wciąż znacznie mocniej podkreślają potrzebę 
dialogu z teorią społeczną. Jeśli chodzi o metodę, KAD zazwyczaj wychodzi od wskazania społecznego problemu (np. rasizm lub homofobia), a następnie przygląda się konkretnym danym, starając się pokazać przykłady tego rodzaju dyskursu, jego recepcji, reprodukcji, ale też odrzucenia. Krytycy twierdzą, że takie podejście prowadzi do dobierania danych tak, by potwierdzały tezę badacza. W zakresie teorii KAD uznaje też zazwyczaj realistyczną wizję rzeczywistości, podczas gdy poststrukturalistyczna analiza dyskursu kładzie nacisk na skonstruowaną naturę porządku społecznego, przyjmując postawę antyhumanistyczną. Podczas gdy KAD, wciąż popularny głównie wśród lingwistów, rozpoczyna od problemu społecznego, który przedstawiany jest jako istniejący realnie, to poststrukturalizm, znacznie bardziej rozpowszechniony wśród konstruktywistów należących do różnych dziedzin nauk społecznych, pyta, w jaki sposób problemy społeczne stają się „realne” poprzez praktyki dyskursywne.

Pomimo tych różnic Krytyczna Analiza Dyskursu i poststrukturalistyczna analiza dyskursu mogą być postrzegane jako dwa wyrazy tego samego dążenia do opisania językowego wymiaru zjawisk społecznych. Wyłonienie się podejść poststrukturalistycznych w badaniach nad akademikami i intelektualistami stanowi przedłużenie krytycznych ambicji KAD i znaczący krok do przodu, jeśli chodzi o wymianę pomiędzy dyscyplinami lingwistyki i teorii społecznej.

\section{Społeczne Badania Szkolnictwa Wyższego - szkolnictwo wyższe jako wiedza/władza}

Wpływ poststrukturalizmu był w ostatnich dekadach odczuwalny przede wszystkim w teorii społecznej, teorii kultury i teorii politycznej, co nie przekładało się na znaczącą obecność w empirycznych badaniach nad szkolnictwem wyższym czy to w nurtach lingwistycznych, czy społecznych. A jednak poststrukturalizm może wnieść istotny wkład w badania nad kontekstami akademickimi. Pozwala on bowiem pokonać opisany powyżej rozziew między nurtami skupiającymi się na władzy i wiedzy w ramach instytucji akademickich, a także pozwala na uwzględnienie języka jako medium, poprzez które jednostki wchodzą do społecznego świata akademii. W kolejnej części tekstu przedstawimy zatem interdyscyplinarną ramę pozwalającą na analizę szkolnictwa wyższego, ze szczególnym uwzględnieniem aspektu dyskursu (Angermuller, 2013b; 2010). Obszar ten - Społeczne Badania Szkolnictwa Wyższego - czerpie z istniejących badań nad szkolnictwem wyższym we wszystkich opisanych powyżej obszarach i skupia się na badaniu praktyk pozycjonowania akademików. 
Perspektywa poststrukturalistyczna odchodzi od wizji szkolnictwa wyższego jako obiektywnej przestrzeni społecznej, którą może być zaobserwowana i opisana przez naukowca-obserwatora. Uwaga badacza skupia się raczej na procesach produkowania i reprodukowania rzeczywistości szkolnictwa wyższego za pomocą heterogenicznych praktyk społecznych. Podejścia strukturalistyczne postrzegały szkolnictwo wyższe przede wszystkim jako instytucjonalną strukturę w społeczeństwie, poststrukturaliści zaś zwracają uwagę głównie na jego aspekt procesualny, który może być zaobserwowany w praktykach akademików. Przyświeca im dążenie do poznania, w jaki sposób naukowcy „robią” porządek społeczny w akademii, niezależnie od teorii i intencji, które temu towarzyszą.

W perspektywie poststrukturalistycznej badacze i badaczki są kreatywni w tym, co robią, mówią i myślą. Nigdy nie kopiują po prostu rozwiązania, które już raz zadziałało, nie zawsze kontrolują też praktyki społeczne i procesy, w których biorą udział. Oczywiście zdarza się, że działają w sposób wykalkulowany, przykładowo publikując w określonej dziedzinie, by zbudować swoją pozycję jako ekspertów. Lecz to zawsze inni aktorzy definiują, kim są w kontekście społecznym. Przykładowo, jeśli nie jest się uznanym przez innych reprezentantów dyscypliny, nie można być jej pełnym członkiem.

A zatem żaden pojedynczy aktor społeczny nie kontroluje w pełni sytuacji. W praktyce społecznej każdy potrzebuje innych, którzy odpowiedzą na działanie, przytakną stwierdzeniu lub po prostu uznają czyjąś obecność. Praktyki społeczne opierają się też na określonych środkach. Aktorzy społeczni mogą mobilizować mniejszą lub większą ich ilość, by zrealizować określone praktyki - możemy tu pomyśleć o materialnych środkach, takich jak czas, pieniądze, relacje (kapitały u Bourdieu), których aktorzy potrzebują, by budować i udoskonalać swoje pozycje podmiotów w szkolnictwie wyższym. Możemy też przytoczyć środki semiotyczne niezbędne w praktykach związanych $\mathrm{z}$ wytwarzaniem znaczenia - wyrażenia i środki lingwistyczne, których ludzie używają, by realizować akty mowy w konkretnych sytuacjach. "Język” może być więc rozumiany jako całość semiotycznych (tj. lingwistycznych i nielingwistycznych) środków, które członkowie wspólnoty wykorzystują w celu angażowania się w praktyki dyskursywne.

Szkolnictwo wyższe jest światem, w którym akademicy korzystają z rozmaitych środków w celu negocjowania porządku społecznego. Z punktu widzenia poststrukturalistycznej teorii dyskursu te środki są jednocześnie materialne i semiotyczne - często trudno jest rozgraniczyć jedne i drugie. Pytanie brzmi: w jaki sposób są one ze sobą związane? Przykładowo, badacze często cytowani w tekstach mogą być wynagradzani za to w sposób materialny przez instytucje, zaś materialne środki są reprezentowane przez medium symbolicz- 
ne (np. pieniądze to uprzedmiotowiona władza ekonomiczna) (Angermuller, 2017).

Analityczne podejścia dyskursywne wpisujące się w dyscyplinę lingwistyki, takie jak teoria enuncjacji (Angermuller, 2014), pokazują, w jaki sposób tekst i mowa ( $w$ formie praktyk takich jak nauczanie, publikowanie, ewaluowanie, wymiana korespondencji, plotkowanie...) definiują relacje z innymi uczestnikami dyskursu akademickiego, konstytuują pozycje akademickich podmiotów i uczestniczą $\mathrm{w}$ procesie produkowania i reprodukowania społecznego porządku w wyższej edukacji. Jednak porządek społeczny jest konstytuowany nie tylko poprzez użycie przez uczestników akademickiego dyskursu języka "naturalnego" i nie tylko przez ludzkich aktorów. W analizie powinno się uwzględnić także aspekt numeryczny, obrazy, gesty, aspekt cielesny (płeć, kolor skóry etc.). Z punktu widzenia poststrukturalizmu porządek społeczny negocjowany jest poprzez praktyki dyskursywne obejmujące rozmaitych aktorów i różne środki.

Podejście Społecznych Badań Szkolnictwa Wyższego, bazujące na poststrukturalistycznej teorii i czerpiące z metod lingwistyki (jak teoria enuncjacji, analiza narracyjna, analiza gatunków...), wychodzi poza istniejące podziały w badaniach nad szkolnictwem wyższym na następujące trzy sposoby:

1) łącząc perspektywy makro i mikro w badaniu społecznej dynamiki wyższej edukacji;

2) uzupełniając metodologiczny deficyt poststrukturalistycznej teorii dyskursu poprzez dostarczenie narzędzi pozwalających na badanie empirycznych obiektów społecznych;

3) umożliwiając pokonanie podziału pomiędzy usytuowanymi w różnych dyscyplinach nurtami wyspecjalizowanymi w badaniu władzy, wiedzy i nauczania.

\section{Podsumowanie}

W tym artykule omówiliśmy bieżące trendy w badaniach nad szkolnictwem wyższym jako zespołem praktyk społecznych. Szkolnictwo wyższe było obiektem zainteresowania wielu dyscyplin i pól: praktyki społeczne związane z produkcją wyspecjalizowanej wiedzy były badane w ramach Science and Technology Studies (STS), praktyki dotyczące instytucjonalnej władzy są obszarem szczególnego zainteresowania Badań Szkolnictwa Wyższego (Higher Education Studies), zaś praktyki edukacyjne należą do istotnych zainteresowań pedagogiki i lingwistyki. Dyskurs stanowi problematykę, która łączy wszystkie trzy powyższe obszary. Ist- 
nieje długa tradycja badań nad dyskursem w środowisku lingwistów badających interakcje w klasie (classroom discourse) lub akademickie praktyki pisania (analiza rodzaju, retoryka nauki) oraz szeroko rozumianą akademicką komunikację (np. w ramach analizy narracyjnej). Lecz, jak wykazaliśmy powyżej, badacze i badaczki z pól takich jak STS i Badania Szkolnictwa Wyższego także interesują się niektórymi aspektami dyskursu np. usytuowanymi społecznie praktykami działania poprzez język (Latour) lub semiotycznym wymiarem społecznych nierówności i władzy instytucjonalnej w akademii (Bourdieu).

Argumentujemy, że zainteresowanie tematyką dyskursu i społecznego konstruowania znaczenia wśród badaczy z tak wielu różnych pól jest symptomem „zwrotu dyskursywnego" w badaniach nad szkolnictwem wyższym. Uwzględnienie czynnika dyskursu jest kluczowe, jeśli chcemy opisać przecinanie się pól władzy, (wytwarzania) wiedzy i (praktyk) nauczania w szkolnictwie wyższym. Wypracowane w ramach nurtów KAD i poststrukturalistycznej analizy dyskursu podejścia pozwalają łączyć perspektywy mikro i makro. Prócz tego, umożliwiają one łączenie złożonej teorii społecznej ze szczegółowymi metodami empirycznej analizy tekstu, często stworzonymi przez badaczy z obszaru pragmatyki. Tekst powyższy jest pomyślany jako zaproszenie badaczy i badaczek do owocnej wymiany pomiędzy podejściami z poziomu makro i mikro, socjologicznymi i lingwistycznymi. Mamy nadzieję, że rosnące zainteresowanie praktykami dyskursywnymi w szkolnictwie wyższym nie tylko pozwoli pokonać podziały między istniejącymi nurtami badań, ale również przyczyni się do utworzenia nowego pola - Społecznych Badań Szkolnictwa Wyższego.

Przełożyła Marta Natalia Wróblewska

\section{Literatura}

Angermuller J. (2013a). Discours académique et gouvernementalité entrepreneuriale. Des textes aux chiffres. [W:] M. Temmar, J. Angermuller, F. Lebaron (eds.). Les discours sur l'économie. Paris, s. 71-84.

Angermuller J. (2013b). How to become an academic philosopher. Academic discourse as a multileveled positioning practice. "Sociología Histórica" 3, s. 263-289.

Angermuller J. (2014). Poststructuralist Discourse Analysis: Subjectivity in Enunciative Pragmatics. Basingstoke, New York.

Angermuller J. (2015). Discourse studies. [W:] J.D. Wright (ed.). International Encyclopedia of the Social \& Behavioral Sciences. 2 nd ed. Amsterdam, s. 510-515. 
Angermuller J. (2017). Academic careers and the valuation of academics. A discursive perspective on status categories and academic salaries in France as compared to the U.S., Germany and Great Britain. "Higher Education" 73(6), s. 963-980. DOI: 10.1007/s10734-017-0117-1.

Angermuller J. (2010). Widerspenstiger Sinn. Skizze eines diskursanalytischen Forschungsprogramms nach dem Strukturalismus. [W:] J. Angermuller, S. v. Dyk (eds.). Diskursanalyse meets Gouvernementalitätsforschung. Perspektiven auf das Verhältnis von Subjekt, Sprache, Macht und Wissen. Frankfurt am Main, s. 71-100.

Angermuller J. (2012). Wissenschaft als Wissen/Macht. Für eine Wissenschaftssoziologie nach dem Strukturalismus. [W:] H.-G. Soeffner (ed.), Transnationale Vergesellschaftungen. Verhandlungen des 35. Kongresses der Deutschen Gesellschaft für Soziologie in Frankfurt am Main 2010. Band 1. Wiesbaden, s. 707-718.

Angermuller J., Maeße J. (2015). Regieren durch Leistung. Zur Verschulung des Sozialen in der Numerokratie. [W:] A. Schäfer, C. Thompson (eds.), Leistung. Paderborn, s. 61-108.

Angermuller J., Maingueneau D., Wodak, R. (2014). The discourse studies reader: an introduction. [W:] J. Angermuller, D. Maingueneau, R. Wodak (eds.), The Discourse Studies Reader. Main currents in theory and analysis. Amsterdam-Philadelphia, s. 16-36.

Antaki C., Billig M., Edwards D., Potter J. (2003). Discourse analysis means doing analysis: A critique of six analytic shortcomings. http://www.shu.ac.uk/daol/articles/v1/n1/a1/antaki2002002-t.html.

Ashmore M. (1989). The Reflexive Thesis. Writing Sociology of Scientific Knowledge. Chicago.

Austin J.L. (1962). How To Do Things with Words. Oxford.

Baert P. (2012). Positioning theory and intellectual interventions. "Journal for the Theory of Social Behaviour" 42(3), s. 304.

Ball S.J. (1990). Foucault and Education: Disciplines and Knowledge. London-New York.

Ball S.J. (2013). Foucault, Power, and Education. New York.

Bamberg M. (1997). Positioning between structure and performance "Journal of Narrative and Life History", 7(1-4), s. 335-342.

Bamberg M. (2010). Who am I? Narration and its contribution to self and identity. "Theory \& Psychology" (21), s. 1-22.

Bazerman C. (1988). Shaping Written Knowledge: The Genre and Activity of The Experimental Article in Science. Madison, Wis.

Bhatia V.K. (1993). Analysing Genre: Language Use in Professional Settings. London-New York.

Cohen M.D., March J.G., Olsen J.P. (1972). A garbage can model of organizational choice. "Administrative Science Quarterly" 17(1), s. 1-25.

Coulthard M. (1992). Advances in Spoken Discourse Analysis. London-New York.

Davies B., Bansel P. (2010). Governmentality and academic work: shaping the hearts and minds of academic workers. "JCT: Journal of Curriculum Theorizing" 26(3), s. 5-20.

Ducrot O. (2014). Outline of a polyphonic theory of enunciation. [W:] J. Angermuller, D. Maingueneau, R. Wodak (eds.), The Discourse Studies Reader. Main Currents in Theory and Analysis. Amsterdam, s. 167-175.

Duszak A., Kowalski, G. (2015). Academic (Inter)genres: between Texts, Contexts and Identities. Bern.

Fahnestock J. (1999). Rhetorical Figures in Science. Oxford.

Fairclough N. (1993). Critical discourse analysis and the marketization of public discourse: the universities. "Discourse \& Society" 4(2), s. 133-168.

Fairclough N. (2007). Global Capitalism and Change in Higher Education: Dialectics of Language and Practice, Technology, Ideology. Paper presented at the BAAL Conference 2007. 
Flowerdew J. (1993). An educational, or process, approach to the teaching of professional genres. "ELT Journal" 47, s. 305-316.

Foucault M. (1972). The Archaeology of Knowledge \& the Discourse on Language. New York.

Fowler R., Hodge B., Kress G., Tony T. (1979). Language and Control. London-Boston.

Frank D.J., Meyer J.W. (2007). Worldwide expansion and change in the university. [W:] G. Krücken, A. Kosmützky, M. Torka (eds.), Towards a Multiversity? Universities between Global Trends and National Traditions. Bielefeld, s. 19-44.

Garton S., Richards K. (2008). Professional Encounters in TESOL. Discourses of Teachers in Teaching. Palgrave.

Gee J. (2015). Social Linguistics and Literacies Ideology in Discourses. Florence.

Gilbert G.N., Mulkay M. (1984). Opening Pandora's Box: a sociological analysis of scientist's discourse. Cambridge.

Gill R. (2009). Breaking the silence: The hidden injuries of neo-liberal academia. [W:] R. Flood, R. Gill (eds.), Secrecy and Silence in the Research Process: Feminist Reflections. London.

Gross A.G. (1990). The Rhetoric of Science. Cambridge.

Gross A.G., Harmon J.E., Reidy M. (2002). Communicating Science: The Scientific Article from the 17 th Century to the Present. New York.

Gross N. (2002). Becoming a pragmatist philosopher: status, self-concept, and intellectual choice. "American Sociological Review" 67(1), s. 52-76.

Hamann J. (2015). "Let us salute one of our kind." How academic obituaries consecrate research biographies. "Poetics" 56, s. 1-14, DOI: http://dx.doi.org/10.1016/j.poetic.2016.02.005.

Harré R., Van Langenhove L. (1999). Positioning Theory: Moral contexts of intentional action. Oxford. Harris R. (2007). The Semantics of Science. London.

Hicks D., Potter, J. (1991). Sociology of scientific knowledge. A reflexive citation analysis or Science disiplines and disciplining sciences. "Social Studies of Science" 21(3), s. 459-501.

Hyland K. (2009). Academic Discourse English in a Global Context. London.

Hyland K., Hyland F. (2006). Feedback in Second Language Writing: Contexts and Issues. Cambridge. Hyland K., Shaw P. (2016). The Routledge Handbook of English for Academic Purposes. Oxford.

Jessop B., Fairclough N., Wodak R. (2008). Education and the Knowledge Based Economy in Europe. Rotterdam.

Keith W., Rehg W. (2009). Argumentation in science: the cross-fertilization of argumentation theory and science studies. [W:] W. Rehg (ed.), Cogent Science in Context. The Science Wars, Argumentation Theory, and Habermas. Cambridge, Mass.

Knorr Cetina, K. (1981). The Manufacture of Knowledge. An Essay on the Constructivist and Contextual Nature of Science. Oxford-New York.

Lamont M.L. (2009). How Professors Think: Inside the Curious World of Academic Judgment. Cambridge, Mass.

Latour B. (1987). Science in Action: How To Follow Scientists and Engineers Through Society. Cambridge, Mass.

Lemke J.L. (1992). Using Language in the Classroom. Oxford.

Luhmann N. (1998). Die Wissenschaft der Gesellschaft. Frankfurt am Main.

Maasen S., Weingart P. (2000). Metaphors and the Dynamics of Knowledge. London.

Maingueneau D. (2002). Analysis of an academic genre. "Discourse Studies" 4(3), s. 319-342.

Masschelein J. (2007). The Learning Society from the Perspective of Governmentality. Malden, MA.

McClosky D.N. (2009). The Rhetoric of Economics. Madison. 
Merton R.K. (1968). Social Theory and Social Structure (1968 enl. ed.). New York.

Mulkay M., Potter J., Yearley S. (1983). Why an analysis of scientific discourse is needed. [W:] K. Knorr Cetina, M. Mulkay (eds.), Science Observed. Perspectives on the Social Study of Science. London, s. $171-203$.

Münch R. (2014). Academic Capitalism: Universities in the Global Struggle for Excellence. Abingdon-Oxon.

Musselin C. (2009). The Market for Academics. London.

Myers G. (1985). The social construction of two biologists' proposals. "Written Communication" 2(3), s. $219-245$.

Myers G. (1989). The pragmatics of politeness in scientific articles. "Applied Linguistics" 10(1), s. 1-35.

Myers G. (1990). Writing Biology: Texts in the Social Construction of Scientific Knowledge. Madison, Wis.

Myers G. (1995). From discovery to invention: the writing and rewriting of two patents. "Social Studies of Science" 25, s. 57-105.

Nesi H., Gardner S. (2012). Genres Across the Disciplines: Student Writing in Higher Education. Cambridge.

Perelman C., Olbrechts-Tyteca L. (1969). The New Rhetoric: a Treatise on Argumentation. Notre Dame, Ind.

Peters M.A., Olssen M. (2009). Governmentality Studies in Education. Rotterdam.

Popow M. (2016). Kategoria narodu w dyskursie edukacyjnym. Analiza procesów konstruowania tożsamości w podręcznikach szkolnych. Poznań.

Porter J.E. (1992). Audience and Rhetoric: An Archaeological Composition of the Discourse Community. Englewood Cliffs.

Power M. (1997). The Audit Society: Rituals of Verification. Oxford-New York.

Reershemius G. (2012). Research cultures and the pragmatic functions of humor in academic research presentations: A corpus-assisted analysis. "Journal of Pragmatics" 44(6-7), s. 863-875.

Rehg W. (2009). Science as argumentative practice. [W:] W. Rehg (Ed.), Cogent Science in Context the Science Wars, Argumentation Theory, and Habermas Cambridge, Mass., London.

Rose N. (1999). Governing the Soul: The Shaping of the Private Self. Sidmouth.

Sinclair J.M., Coulthard R.M. (1981). Towards an Analysis of Discourse: The English Used by Teachers and Pupils. London.

Skinner Q. (1988). Meaning and understanding in the history of ideas. [W:] J. Tully (ed.), Meaning and Context. Quentin Skinner and his Critics. Cambridge, s. 29-67.

Swales J.M. (1990). Genre analysis: English in Academic and Research Settings. Cambridge-New York.

Swales J.M. (1998). Other Floors, Other Voices: A Textography of a Small University Building. Mahwah N.J.

Swales J.M. (2011). Aspects of Article Introductions. Ann Arbor.

Thomas J. (2013). Meaning in Interaction: An Introduction to Pragmatics. New York.

Van Dijk T.A. (1990). Discourse \& Society: a new journal for a new research focus. "Discourse \& Society" 1(1), s. 5-16. doi:10.1177/0957926590001001001.

Ylijoki O.-H. (2005). Academic nostalgia: A narrative approach to academic work. "Human Relations" 58(5), s. 555-576. doi: 10.1177/0018726705055963. 